\title{
Impact of Debt Structure, State Ownership on Business Performance in Energy Enterprises: A Case Study in Vietnam
}

\author{
Nguyen Thi Xuan Hong, Dang Ngoc Hung* \\ Faculty of Accounting and Auditing, Hanoi University of Industry, Hanoi, Vietnam
}

Received December 2, 2021; Revised January 9, 2022; Accepted February 16, 2022

\section{Cite This Paper in the following Citation Styles}

(a): [1] Nguyen Thi Xuan Hong, Dang Ngoc Hung, "Impact of Debt Structure, State Ownership on Business Performance in Energy Enterprises: A Case Study in Vietnam," Universal Journal of Accounting and Finance, Vol. 10, No. 2, pp. 509 - 516, 2022. DOI: 10.13189/ujaf.2022.100215.

(b): Nguyen Thi Xuan Hong, Dang Ngoc Hung (2022). Impact of Debt Structure, State Ownership on Business Performance in Energy Enterprises: A Case Study in Vietnam. Universal Journal of Accounting and Finance, 10(2), 509 - 516. DOI: 10.13189/ujaf.2022.100215.

Copyright $\bigcirc 2022$ by authors, all rights reserved. Authors agree that this article remains permanently open access under the terms of the Creative Commons Attribution License 4.0 International License

\begin{abstract}
This study examines the impact of debt structure and the interaction of state ownership on business performance of energy enterprises in Vietnam's stock exchange. Data in the study were collected in the period 2009-2020 with 665 observations, the estimated results by the GLS regression model show that short-term debt and long-term debt have a negative impact on business performance when measured by ROA and Tobin's Q. In energy enterprises in Vietnam, the state often holds the dominant stock, so in this study, we consider the impact of the interaction margin of state ownership, this study finds that the interaction of state ownership and short-term debt have a positive effect on business performance measured by ROA. In addition, the study also looks into control variables, namely firm size, liquidity ratio and asset structure that have a positive impact on business performance. We provide some recommendations to improve capital structure and business performance: Energy companies need to build an optimal capital structure to maximize business value; Investors can quantify the model to decide whether or not to invest or how much to invest in an energy business; The government needs to look into and consider holding a controlling stake in energy enterprises that are really necessary and bring good business results.
\end{abstract}

Keywords Debt Structure, Business Performance, State Ownership, Energy Business

\section{Introduction}

Energy plays a key role for sustainable development and global climate change response. For Vietnam, energy plays a key role in the process of industrialization and modernization. The government has shown its determination and given high priority to efforts to ensure national energy security and provide enough energy for socio-economic development. Vietnam's energy demand is growing rapidly, especially electricity. The demand for electricity in Vietnam is always growing at a high rate. This requires large investment capital and just the state budget alone cannot meet such requirement.

Efficiency is the core issue in production and business activities. It is the overall long-term goal for all enterprises in general and enterprises in the energy industry in particular. The business performance of an enterprise is evaluated through ratios that measure its profitability and achievement based on book value and market value. The construction of debt structure also plays a very important role for financial managers; it contributes directly to the business value and has the ability to amplify income for company owners. Enterprises often raise business capital from many different sources (issuing stocks, bonds or borrowing from banks, credit institutions). The choice of funding sources according to the structure of short-term debt or long-term debt with what proportion has a great impact on the business performance of an enterprise. Therefore, the relationship between business performance 
and debt structure of enterprises is considered an important issue and should be given due attention.

If an enterprise uses too much debt, it will easily fall into a state of financial distress. By then, the use of debt is no longer beneficial to the business and enterprises face a very high risk of bankruptcy. This shows that capital structure plays a very important role in deciding the survival of enterprises. An optimal capital structure is the one where firm value is highest and average cost of capital is lowest. Energy has always been an important factor in socio-economic development in Vietnam as well as in the world. In order to realize the goal of fast and sustainable economic development, striving to turn our country basically into a modern industrialized country as soon as possible, the Government has always paid great attention to the issue of energy development, especially the development of green energy today is the trend of the world, rapidly changing the structure of the energy industry. With the current progress of development in the economy and high energy demand, the interest rate level in recent years has been stable, the urbanization rate is high, the population structure is young, and the average income per capita has been improved, leading to a huge demand for housing and infrastructure. Changes in infrastructure will create a strong attraction for energy industry projects to develop, leading to more growth and development in the energy industry in the future. The energy industry plays a pivotal and leading role in a number of industries and fields, so the government holds the dominant ownership percentage. How will the interaction of state ownership with debt structure affect the business performance of enterprises? In this study, we will examine the interaction between state ownership and debt structure that affects business performance.

\section{Literature Review}

Modigliani and Miller's theory of corporate capital structure: The first theory to study the capital structure of enterprises and also the basic premise for later theories is Modigliani and Miller [1]. That theory is based on the proposition that in a perfectly competitive market, capital structure does not affect firm value, or in other words, all combinations of equity and liabilities produce the same result and all of those combinations don't change the value of the business. To put it differently, in a world without corporate taxes, the value of enterprises with debt and without debt is the same. Then Modigliani and Miller [2] added corporate income tax to the model and showed that with corporate income tax, the business value of using debt equals the business value without debt value plus the value of the benefit from using debt. Interest is a reasonable expense that is deducted from expenses when calculating corporate income tax, so debt-using companies will benefit from deducting interest expenses.

The trade-off theory of capital structure: This is a theory in the field of corporate finance developed by Kraus and Litzenberger [3] which aimed towards an optimal capital structure and explained why enterprises are often financed partly by debt and partly by equity. A big reason why enterprises cannot be financed $100 \%$ with debt is because using debt benefits from the present value of the tax shield, but using too much debt also comes with costs, such as the cost of financial distress. Due to the excessive use of debt financing, there will come a time when the present value of the benefits of the tax shield is no longer sufficient to offset the present value of the costs of financial distress. By then, debt financing no longer benefits enterprises but reduces the business value of through interest payments that reduce profits. So, to optimize firm value, enterprises rely on this offsetting principle to determine what percentage of debt and what percentage of equity to choose establish optimal capital structure.

Agency cost theory: Agency costs are costs incurred when an organization encounters disagreements about the goals of owners and managers and asymmetric information problems, it can also be said that agency costs are losses when managers do not try to maximize firm value. The cause of agency costs is the conflict of interest between shareholders and managers, between creditors and shareholders, between managers and employees, and between groups of shareholders. The existence of the agency cost in the enterprise shows the development of the enterprise large scale and professional level of executive management. However, the existence of agency costs also implies that there will be an increase in administrative costs of the business if the benefits from agency contracts are not enough to offset agency costs, thereby reducing profits and reducing costs affect the performance of the company [4].

The pecking order theory: This theory gives the priority order of the capital structure of the enterprise. It makes two rules when a company needs to raise more capital. The first rule is to use internal funding through retained earnings or development funds. The second rule is to issue the safest debt securities. If it is necessary to raise capital from outside, the safest debt securities should be issued first. Only when the company's debt level has reached an acceptable threshold should the company consider issuing equity capital. Thus, the pecking order theory shows that the priority order when using capital is internal financing, debt securities issuance, and equity issuance, respectively.

\section{Research Overview and Hypotheses}

Chadha and Sharma [5] studied the relationship between capital structure and business performance through financial leverage with the panel data of 422 manufacturing companies in India during 2003-2013. Variables representing the financial performance of enterprises are Return on total assets (ROA), return on 
equity (ROE) and Tobin'Q; the variable represents that capital structure is financial leverage. Research results show that financial leverage has a negative effect on ROE but is not statistically significant regarding ROA and Tobin's Q. Salim and Yadav [6] studied the relationship between capital structure and business performance. That study used four dependent variables including: ROE, ROA, Tobin'Q, and earnings per share (EPS). The independent variables included long-term debt, short-term debt, total debt, business growth rate and firm size. Research results show that business performance measured by ROA, ROE, and EPS has an inverse relationship with short-term debt (STD), long-term debt (LTD) and total debt (TD). Furthermore, there is a positive relationship between growth and business performance for all sectors. The Tobin's Q has a positive relationship with STD and LTD. However, TD has a negative relationship with business performance. Ahmad et al [7] studied the relationship between capital structure and business performance in the industrial and consumer sectors using data from 58 companies in Malaysia during 2005-2010. Dependencies in the model include ROA and ROE. The independent variables in the models are financial leverage including short-term debt to total assets, long-term debt to total assets and total debt to total assets. Research results show that financial leverage has a negative effect on ROE and long-term debt on total assets and total debt have a negatively relationship with ROA. San and Heng [8] examined the relationship between capital structure and business performance before and during the crisis. This study focused on construction companies listed on the stock exchange of Bursa Malaysia for the period from 2005 to 2008 with a sample of all 49 construction companies divided into large, medium and large scale, and small based on capital. Research results show that there is a relationship between capital structure and business performance. For large firms, return on capital (ROC) to debt to market value (DEMV) is positively correlated, EPS and long-term debt to capital (LDC) have a positive relationship, while EP) and total debt to capital (DC) have a negative relationship. For medium-sized firms, operating margin (OM) and Debt-to-Common Equity (LDCE) have a positive relationship. For small firms, EPS and DC are negatively correlated.

Saeedi and Mahmoodi [9] used panel data with a sample of 320 companies listed on the Tehra stock exchange during the period 2002-2009. The study used four dependent variables: ROA, ROE, EPS, Tobin'Q and three independent variables including: STD, LTD, and TD. Research results show that business performance measured by EPS and Tobin'Q has a positive correlation with variables representing capital structure. Besides, the research results also show that there is a negative correlation between ROA and variable of proxies for capital structure. The study of Carpentier [10] was conducted on a sample of 243 companies in France in the period 1987-1996. Research results show that firm size is positively correlated with business value and business growth has no statistical significance for business value. Unexpectedly, the results also show that there is no empirical evidence on the correlation between financial leverage and firm value.

Agency cost theory incurred because state shareholders are individual representatives, representative shareholders may not act for the sake of efficiency and the interests of the company leading to ownership. High state has a negative impact on company performance [4]. The pecking order theory explains why profitable firms typically borrow less, not because they have a low target debt ratio, but because they don't need outside money. Less profitable firms issue debt because they do not have sufficient internal funds for capital investment because debt financing ranks first in the pecking order of external financing [3].

Above are some results of scientific studies around the world about relationship between capital structure and business performance of enterprises. We will examine the impact of debt structure including short-term debt and long-term debt on business performance in energy enterprises in Vietnam.

\section{Research Methods and Models}

\section{Research Data}

This study includes all energy companies listed on the stock exchange in Vietnam, period 2009-2020 with 665 observations. We collect research data from audited financial statements (including balance sheet, income statement, cash flow statement and notes to financial statements).

\section{Research Model and Research Hypotheses}

Based on research overview [1], [3], [4], [5], [6], [7], [8], [10] and objectives, we build research model No.1, with the variables briefly described in Table 1.

$$
\begin{aligned}
& \text { Model 1: PERFORMANCE } \\
& \quad+\alpha_{1} \text { SIZE }_{\mathrm{i}, \mathrm{t}}+\alpha_{2} \operatorname{LIQUID}_{\mathrm{i}, \mathrm{t}}+\alpha_{3} \operatorname{ASSET}_{\mathrm{i}, \mathrm{t}}+\beta_{\mathrm{i}, \mathrm{t}}
\end{aligned}
$$


Table 1. Summary of variables in the research model

\begin{tabular}{|c|c|c|c|c|}
\hline Name of variable & Type off variable & $\begin{array}{c}\text { Code of } \\
\text { variable }\end{array}$ & Measurement & $\begin{array}{c}\text { Impact } \\
\text { direction }\end{array}$ \\
\hline $\begin{array}{c}\text { Business } \\
\text { performance }\end{array}$ & Dependent & ROA & ROA = Profit after tax/Total assets & \\
\cline { 2 - 5 } & Dependent & Tobin's Q & Tobin's Q = (Market value + Liabilities)/ Total assets & - \\
\hline Short-term debt & Independent & SDA & SDA = Current Liabilities/Total Assets & - \\
\hline Long-term debt & Independent & LDA & LDA = Long-term debt/Total assets & $+/-$ \\
\hline State ownership & Interaction & STATE & STATE = 1, If state ownership is above 50\%, otherwise \\
\hline Firm size & Control & SIZE & Log (Total asset) & $+/-$ \\
\hline Liquidity ratio & Control & LIQUID & Cash and cash equivalents/Total assets & + \\
\hline Asset structure & Control & ASSET & ASSET = Fixed Assets/Total Assets & + \\
\hline
\end{tabular}

Source: authors' own design

This study aims to investigate the relationship between debt structure and business performance in the energy industry. The independent variable represents the debt structure including short-term debt to total assets, long-term debt to total assets. The dependent variable representing business performance includes ROA and Tobin'Q represents investment opportunities of the enterprise. In addition, we also add to the model the variables of firm size, liquidity ratio and asset structure as control variables because according to previous studies, these also affect business performance. A high financial leverage ratio indicates that the enterprise's capital structure is consistent with agency cost theory and pecking order theory. The agency cost theory holds that increasing debt to reduce costs incurred when there is a conflict between the company's executives and investors should increase profits, leading to an increase in firm value. The pecking order theory talks about the priority of using debt over equity when needing to increase capital. But also according to the trade-off theory of capital structure, the use of debt only brings benefits to the enterprise at a certain level. If the use of debt is beyond the allowable threshold, the benefits from the use of debt are no longer sufficient to compensate for the additional costs incurred such as financial distress costs. As a result, this causes profits to be reduced and lead to a decrease in the value of the enterprise. Salim and Yadav [6] found that there is a correlation between financial leverage and business performance and that short-term debt, long-term debt and total debt all have negative impacts on business performance. Saeedi and Mahmoodi [9] pointed out that short-term debt, long-term debt, and total debt have negative impacts on return on total assets. Inheriting the above research results, we develop the following hypothesis:

Hypothesis 1: Short-term debt has a negative relationship with business performance of energy enterprises.

Hypothesis 2: Long-term debt has a negative relationship with business performance of energy enterprises.
In addition, one of the reasons leading to conflicting conclusions about the relationship between capital structure and business performance is that most of the previous studies only looked at the relationship between capital structure and business performance debt and business performance. A study by Chao [11] also concluded that ownership structure has an interactive impact on the relationship between debt structure and business performance of electronics companies listed in Taiwan. For the purpose of the study, we consider the interactive impact of ownership structure, represented by the state ownership ratio, on the relationship between debt structure and business performance. Okuda and Nhung [12] showed that firms controlled by the state (the state owns more than $50 \%$ of capital) have little incentive to save income tax by using debt because corporate income tax also provides significant revenue for the state. In addition, Alfaraih et al. [13] argued that state control is sometimes for policy purposes rather than business, and thus has the potential to influence the impact of debt on business efficiency. Therefore, model 2 and hypothesis are built as follows:

$$
\begin{array}{r}
\text { Model 2: PERFORMANCE }{ }_{\mathrm{i}, \mathrm{t}}=\beta_{0}+\beta_{1} \mathrm{SDA}_{\mathrm{i}, \mathrm{t}}+\beta_{2} \mathrm{LDA}_{\mathrm{i}, \mathrm{t}}+ \\
\beta_{3} \text { SDA_STATE }_{\mathrm{i}, \mathrm{t}}+\beta_{4} \mathrm{LDA}_{2} \text { STATE }_{\mathrm{i}, \mathrm{t}}+\alpha_{1} \operatorname{SIZE}_{\mathrm{i}, \mathrm{t}}+\alpha_{2} \\
\operatorname{LIQUID}_{\mathrm{i}, \mathrm{t}}+\alpha_{3} \mathrm{ASSET}_{\mathrm{i}, \mathrm{t}}+\varepsilon_{\mathrm{i}, \mathrm{t}}
\end{array}
$$

Hypothesis 3: The interaction of state ownership and short-term debt affect business performance of energy enterprises.

Hypothesis 4: The interaction of state ownership and long-term debt affect business performance of energy enterprises.

\section{Data Analysis Method}

We use the GLS method (Generalized least squares). This method has the advantage of overcoming the defects of the model such as autocorrelation, variable variance, so the research results are reliable. 
Table 2. Descriptive Statistics

\begin{tabular}{cccccc}
\hline Variable & $\begin{array}{c}\text { Number of } \\
\text { observation }\end{array}$ & Mean & Standard deviation & Min value & Max value \\
\hline ROA & 665 & 0.067 & 0.067 & -0.185 & 0.416 \\
TobinQ & 665 & 0.981 & 0.401 & 0.331 & 4.196 \\
SDA & 665 & 0.336 & 0.209 & 0.007 & 0.914 \\
LDA & 665 & 0.201 & 0.189 & 0.000 & 0.787 \\
SIZE & 665 & 27.812 & 1.528 & 23.312 & 31.898 \\
LIQUID & 665 & 0.103 & 0.132 & 0.000 & 0.899 \\
ASSET & 665 & 0.380 & 0.278 & 0.001 & 0.978 \\
\hline
\end{tabular}

Table 3. Difference test

\begin{tabular}{|c|c|c|c|c|}
\hline & \multicolumn{2}{|c|}{ State ownership ratio } & \multirow{2}{*}{$\mathrm{t}$} & \multirow{2}{*}{ sig } \\
\hline & $<=50 \%$ & $>50 \%$ & & \\
\hline ROA & 0.073 & 0.064 & 1.5596 & 0.1193 \\
\hline TobinQ & 1.031 & 0.953 & 2.4275 & 0.0155 \\
\hline SDA & 0.324 & 0.343 & -1.1254 & 0.2608 \\
\hline LDA & 0.168 & 0.220 & -1.1254 & 0.2608 \\
\hline SIZE & 27.514 & 27.980 & -3.816 & 0.0001 \\
\hline LIQUID & 0.121 & 0.092 & 2.7514 & 0.0061 \\
\hline ASSET & 0.379 & 0.381 & -0.0826 & 0.9342 \\
\hline
\end{tabular}

Table 4. Correlation Matrix

\begin{tabular}{|c|c|c|c|c|c|c|c|}
\hline & ROA & TobinQ & SDA & LDA & SIZE & LIQUID & ASSET \\
\hline ROA & 1 & & & & & & \\
\hline TobinQ & $0.4332 *$ & 1 & & & & & \\
\hline SDA & $-0.2827 *$ & $-0.1235 *$ & 1 & & & & \\
\hline LDA & $-0.2701 *$ & $-0.1290 *$ & $-0.4483^{*}$ & 1 & & & \\
\hline SIZE & $-0.0870 *$ & 0.1129* & $-0.1093^{*}$ & $0.3521^{*}$ & 1 & & \\
\hline $\begin{array}{l}\text { LIQUI } \\
\text { D }\end{array}$ & $0.3742 *$ & $0.2731^{*}$ & 0.0014 & $-0.3290 *$ & 0.036 & 1 & \\
\hline ASSET & 0.0046 & 0.0109 & $-0.5083^{*}$ & $0.5753^{*}$ & $0.1364 *$ & $-0.2976 *$ & 1 \\
\hline
\end{tabular}

$\mathrm{t}$ statistics in brackets ${ }^{*} \mathrm{p}<0.05$

\section{Research Results and Discussion}

Descriptive statistical results are presented in Table 2; ROA is $6.7 \%$ and Tobin's Q is 0.981 less than 1 . Such results show that energy companies seem to have good business results. The average leverage ratio of energy enterprises is $53.7 \%$, of which short-term debt accounts for a high proportion of $33.6 \%$, the highest ratio of short-term debt is up to $91.7 \%$, and the ratio of long-term debt, of enterprises in the energy industry is $20.1 \%$. The average debt utilization rate in Vietnam is quite high compared to neighboring countries. Typically, the study by Huang and Song [14] with a sample of more than 1,200 companies in China during 1994-2003 showed the average debt ratio of firms in China is $30 \%$. In addition, we also see that energy enterprises in Vietnam tend to use short-term debt more than use long-term debt.

Table 3 presents the results of the mean value of variables in the research model and results of verifying the difference between the two groups with the state ownership rate above and below $50 \%$. The results show that $3 / 7$ variables have the difference and statistical significance; the variables that have the difference and have statistical significance are Tobin's Q index, enterprise size (SIZE) and liquidity ratio (LIQUID) of energy enterprises.

Looking at Table 4 of the correlation matrix among variables, we see that the correlation among the variables is low, which shows that the independent variables and the dependent variables have little impact on each other, so there is no possibility of multivariable phenomenon. The ratio of short-term debt to total assets (SDA) has a negative relationship with ROA, Tobin's Q with correlation coefficients of $-0.2827,-0.1235$, respectively; at the same time, the ratio of long-term debt to total assets (LDA) has a negative relationship with Tobin's $\mathrm{Q}$ with correlation coefficients of $-0.2701,-0.129$, respectively. The results of 
the autocorrelation analysis show that using more debt (both short-term debt and long-term debt) makes ROA and Tobin's Q lower. At the same time, Table 4 gives the results of the correlation coefficient between the variables, the purpose of testing the close correlation between the independent variables and the dependent variable is to remove the factors that can lead to the phenomenon of multicollinearity before running the regression model. The correlation coefficient between the independent variables in the model has no pair greater than 0.8 , so there is little possibility of multicollinearity. When using the author group regression model, the VIF coefficient is used for checking.

Regression results show that business performance measured by ROA variable and by Tobin'Q has a negative relationship with SDA and LDA with statistical significance level at $1 \%$. With the results of Table 5, hypothesis 1 and hypothesis 2 are accepted; this result is similar to the research results of Salim and Yadav [6]. For control variables, firm size (SIZE) has a positive effect on Tobin'Q, but has no statistical significance regarding business performance when measured by ROA. Besides, liquidity ratio and asset structure have a positive relationship with business performance. Research results are similar to those of [15], [16], [17], [18], [19]

Table 5. Regression results of model 1

\begin{tabular}{ccc}
\hline & ROA & TobinQ \\
\hline SDA & $-0.134^{* * *}$ & $-0.305^{* * *}$ \\
& {$[-10.74]$} & {$[-3.59]$} \\
LDA & $-0.156^{* * *}$ & $-0.536^{* * *}$ \\
& {$[-10.00]$} & {$[-5.03]$} \\
SIZE & -0.000198 & $0.0421^{* * *}$ \\
& {$[-0.13]$} & {$[4.08]$} \\
LIQUID & $0.136^{* * *}$ & $0.665^{* * *}$ \\
& {$[7.59]$} & {$[5.44]$} \\
ASSET & $0.0305^{* * *}$ & $0.171^{* *}$ \\
& {$[3.00]$} & {$[2.47]$} \\
\multirow{2}{*}{ cons } & $0.124^{* * *}$ & -0.112 \\
& {$[3.00]$} & {$[-0.40]$} \\
\hline $\mathrm{N}$ & 665 & 665 \\
\hline
\end{tabular}

t statistics in brackets $* \mathrm{p}<0.1, * * \mathrm{p}<0.05, * * * \mathrm{p}<0.01$

Besides the relationship between capital structure and business performance, this study also examines the interactive role of state ownership on this relationship. The estimated results of model 2 in Table 6 show that there is a positive effect of short-term debt on business performance when measured by ROA, which means that business performance will become better in the long run in case the company is controlled by the government (the government owns $50 \%$ or more of the total capital). This conclusion does not support the finding of Chao [11] that ownership structure has a negative interaction impact on the relationship between capital structure and business performance of listed electronics companies in Taiwan. However, the interaction of state ownership on long-term debt has no impact on business performance when measured by both ROA and Tobin's Q.

Table 6. Results of regression model 2

\begin{tabular}{|c|c|c|}
\hline & ROA & TobinQ \\
\hline \multirow[t]{2}{*}{ SDA } & $-0.156^{* * *}$ & $-0.350 * * *$ \\
\hline & {$[-10.14]$} & {$[-3.32]$} \\
\hline \multirow[t]{2}{*}{ LDA } & $-0.152 * * *$ & $-0.396 * * *$ \\
\hline & {$[-6.89]$} & {$[-2.62]$} \\
\hline \multirow[t]{2}{*}{ SDA_STATE } & $0.0304^{* *}$ & 0.0707 \\
\hline & [2.40] & {$[0.82]$} \\
\hline \multirow[t]{2}{*}{ LDA_STATE } & -0.008 & -0.174 \\
\hline & {$[-0.42]$} & {$[-1.33]$} \\
\hline \multirow[t]{2}{*}{ SIZE } & -0.000591 & $0.0409^{* * *}$ \\
\hline & {$[-0.39]$} & [3.94] \\
\hline \multirow[t]{2}{*}{ LIQUID } & $0.139 * * *$ & $0.674^{* * *}$ \\
\hline & {$[7.75]$} & {$[5.51]$} \\
\hline \multirow[t]{2}{*}{ ASSET } & $0.0282 * * *$ & $0.152^{* *}$ \\
\hline & [2.73] & [2.15] \\
\hline \multirow[t]{2}{*}{ _cons } & $0.136 * * *$ & -0.0767 \\
\hline & [3.29] & {$[-0.27]$} \\
\hline $\mathrm{N}$ & 665 & 665 \\
\hline
\end{tabular}

t statistics in brackets $* \mathrm{p}<0.1,{ }^{* *} \mathrm{p}<0.05,{ }^{* * *} \mathrm{p}<0.01$

To explain this, from the perspective of agency theory, the agency problem, or the conflict of interest between the owner (Principal) and the representative (Agent) in state controlled energy joint stock companies with effective use of debt in Vietnam, this increases the agency cost of equity. Jensen and Meckling [4] argued that, to reduce this agency cost, debt is seen as an effective tool. Meanwhile, the findings of Okuda and Nhung [12] shown that state controlled enterprises are less inclined to use debt as a tax shield because corporate income tax is also a substantial revenue to the government. Thus, with the same high debt ratio, state-controlled enterprises sometimes invest in projects for policy purposes rather than business and profit purposes Alfaraih et al.,[13] or an agent will choose projects that benefit individuals rather than shareholders because of the separation between ownership and management Fama, [20], and thus improve the positive effect of debt on business performance.

Our research results are in agreement with the study of the authors [5], [6], [7]. However, contrary to the study of [9] when measuring business performance according to Tobin'Q, but consensus when measuring business performance according to ROA. 


\section{Conclusions and Recommendations}

The study aims to look at the relationship between debt structure and business performance of energy enterprises listed on the stock exchange in Vietnam. Research results find that short-term debt and long-term debt will reduce business performance as measured by ROA, Tobin's Q. The study finds that debt is negatively correlated with business performance; this result is consistent with the theory of Modigliani and Miller [2], the trade-off theory of capital structure. The reason why debt is negatively correlated with business performance of energy enterprises in Vietnam is because large investment capital flows from abroad into the Vietnamese market are still facing many difficulties and enterprises in need of capital are forced to use more debt to access investment projects and bear many costs incurred when borrowing more debt, thus reducing business efficiency. The research results also find that firm size, liquidity ratio and asset structure are positively related to business performance. Besides, when considering the interaction of state ownership, it was found that in case of interaction of state ownership (over 50\%) with short-term debt there is a positive relationship with business performance when measured by ROA; this, however, does not affect business performance when measured by Tobin's Q. On the other hand, the interaction of state ownership with long-term debt has no effect on business performance. Based on the research results, we propose the following recommendations:

Energy companies need to build an optimal capital structure to maximize business value. Moreover, enterprises should not take out loans until the break-even point has been exceeded because it will amplify losses further to and cause business difficulties. In case an enterprise has used debt to a tolerable level but is still thirsty for capital, it should not borrow more debt at all cost but should restructure capital sources to ensure its operations. In the long term, in other words, energy enterprises in Vietnam should pursue a capital structure that has both debt and equity at the same time. Also, energy enterprises need to study and choose to invest in fixed assets effectively based on the assessment of fixed asset needs; then the investment will bring good business results.

Investors can quantify the model to decide whether or not to invest or how much to invest in an energy business. Besides, although each investor's risk-taking requirement and basis are different, through the analysis results of the study, the authors recommend that they should not invest into enterprises that use too much debt before passing the break-even point. Also, investors should also invest in energy enterprises with high payout ratio, high proportion of fixed assets and good liquidity because these factors will increase business performance.

The government needs to look into and consider holding a controlling stake in energy enterprises that are really necessary and bring good business results. A roadmap is required for divestment in enterprises that are not important to the safety of the national energy and to increase calls for energy projects that use less fossil resources. Also the government should have incentive policies and create a good environment for projects to create green energy sources, for sustainable development.

Thus, based on the trade-off theory of capital structure, creditors will also require a higher rate of return, increasing the firm's cost of capital. Thus, the firm's optimal capital structure is determined by increasing the amount of debt until the marginal benefit from the tax base equals the marginal cost of financial distress. Whereas according to the theory of Modigliani \& Miller [2] using debt gives owners a higher rate of return, this higher return is exactly what they compensate for the increased risk from the rate debt capital relative to total capital, however in an imperfect market the results of this study demonstrate that using more debt reduces firm value.

\section{REFERENCES}

[1] F. Modigliani and M. H. Miller, "The cost of capital, corporation finance and the theory of investment," The American economic review, vol. 48, no. 3. pp. 261-297, 1958, https://www.jstor.org/stable/1809766.

[2] F. Modigliani and M. H. Miller, "Corporate income taxes and the cost of capital: a correction," The American economic review, no. pp. 433-443, 1963, https://www.jstor .org/stable/1809167.

[3] A. Kraus and R. H. Litzenberger, "A state-preference model of optimal financial leverage," The journal of finance, vol. 28, no. 4. pp. 911-922, 1973, https://doi.org/10.1111/j.154 0-6261.1973.tb01415.x.

[4] M. C. Jensen and W. H. Meckling, "Theory of the firm: Managerial behavior, agency costs and ownership structure," Journal of financial economics, vol. 3, no. 4. pp. 305-360, 1976, https://doi.org/10.1016/0304-405X(76)900 26-X.

[5] S. Chadha and A. K. Sharma, "An empirical study on capital structure in Indian manufacturing sector," Global Business Review, vol. 17, no. 2. pp. 411-424, 2016, https://doi.org/10.1177/0972150915619817.

[6] M. Salim and R. Yadav, "Capital structure and firm performance: Evidence from Malaysian listed companies," Procedia-Social and Behavioral Sciences, vol. 65, no. pp. 156-166, 2012,https://doi.org/10.1016/j.sbspro.2012.11.10 5.

[7] Z. Ahmad, N. M. H. Abdullah, and S. Roslan, "Capital structure effect on firms performance: Focusing on consumers and industrials sectors on Malaysian firms," International review of business research papers, vol. 8, no. 5. pp. 137-155, 2012,

[8] O. T. San and T. B. Heng, "Capital structure and corporate performance of Malaysian construction sector," International Journal of Humanities and Social Science, vol. 1, no. 2. pp. 28-36, 2011, 
[9] A. Saeedi and I. Mahmoodi, "Capital structure and firm performance: Evidence from Iranian companies," International Research Journal of Finance and Economics, vol. 70, no. pp. 20-29, 2011,

[10] C. Carpentier, "The valuation effects of long-term changes in capital structure," International Journal of Managerial Finance, no. 2006, https://doi.org/10.1108/1743913061064 6144.

[11] C.-H. Chao, "The Influence of Capital Structure on Organizational Performance at Taiwan-Listed Info-Electronics Companies: Using Corporate Governance as the Moderator," American Journal of Business and Management, vol. 1, no. 2. pp. 60-69, 2012, https://doi.org/10.11634/21679606170694.

[12] H. Okuda and L. T. P. Nhung, "The determinants of the fundraising structure of listed companies in Vietnam: Estimation of the effects of government ownership," Paper presented at the meeting of Global COE HiStat Discussion Paper, Tokyo, Japan., no. 2010,

[13] M. Alfaraih, F. Alanezi, and H. Almujamed, "The influence of institutional and government ownership on firm performance: evidence from Kuwait," International Business Research, vol. 5, no. 10. p. 192, 2012, doi:10.5539/ibr.v5n10p192

[14] G. Huang and F. M. Song, "The determinants of capital structure: Evidence from China," China economic review, vol. 17, no. 1. pp. 14-36, 2006, https://doi.org/10.1016/j.ch ieco.2005.02.007.

[15] N. H. Dang, T. V. H. Hoang, and T. B. Dang, "Impact of accounting information on financial statements to the stock price of the energy enterprises listed on Vietnam's stock market," International Journal of Energy Economics and Policy vol. 8, no. 2. pp. 1-6, 2018,

[16] N. T. T. Phuong, D. N. Hung, V. T. T. Van, and N. T. Xuan, "Effect of Debt Structure on Earnings Quality of Energy Businesses in Vietnam," International Journal of Energy Economics and Policy, vol. 10, no. 3. pp. 396-401, 2020,

[17] T. V. Ha, N. H. Dang, M. D. Tran, T. T. Van Vu, and Q. Trung, "Determinants Influencing Financial Performance of Listed Firms: Quantile Regression Approach," Asian Economic and Financial Review, vol. 9, no. 1. pp. 78-90, 2019, DOI: 10.18488/journal.aefr.2019.91.78.90.

[18] D. Danylyshyn, M. Dubyna, M. Zabashtanskyi, N. Ostrovska, K. Blishchuk, and I. Kozak, "Innovative Instruments of Monetary and Fiscal Policy," Universal Journal of Accounting and Finance, vol. 9, no. 6. pp. 1213 1221, 2021, DOI: 10.13189/ujaf.2021.090601.

[19] J. G. Pagaddut, "The Financial Factors Affecting the Financial Performance of Philippine MSMEs," Universal Journal of Accounting and Finance, vol. 9, no. 6. pp. 1524 1532, 2021, DOI: 10.13189/ujaf.2021.090629.

[20] E. F. Fama, "Agency problems and the theory of the firm," Journal of political economy, vol. 88, no. 2. pp. 288-307, 1980, https://www.jstor.org/stable/1837292. 